\title{
OCTAHEDRAL SUBSTITUTION MECHANISMS AND REACTIVE INTERMEDIATES
}

\author{
A. M. SARGESON \\ Research School of Chemistry, \\ The Australian National University, Canberra, 2600
}

\begin{abstract}
The paper reviews and discusses some aspects of substitution of octahedral complexes in aqueous solution. The areas considered primarily are anation, aquation and substitution in labile and kinetically robust systems. The evidence for the existence of intermediates of reduced coordination number, the characteristics and properties of such intermediates and the implications of these properties in the aforementioned processes are considered. A discussion of some primary aspects of base hydrolysis in octahedral complexes is included. The intermediates derived from these processes and details concerning their lifetime and structure are discussed. Finally, the use of such intermediates for synthesis of labile and thermodynamically unstable products is exemplified. The dissociative character of all this chemistry is offset against the comparative absence of nucleophilic characteristics. The point is made that the absence of nucleophilic paths for electronically rich systems should lead more commonly to the observation of electrophilic reactions and some of the evidence for these is presented.
\end{abstract}

\section{SCOPE AND PURPOSE}

Much has been written on the mechanism of substitution of octahedral coordination complexes and there are numerous reviews which have summarized and evaluated the experiments available. I propose therefore to consider only a few of the areas where uncertainty exists in understanding the substitution process, to review briefly what is known about intermediates of ligancy 5 and to indicate the possible use of these intermediates in synthesis. Even in coping with this limited theme, much of the preliminary work is neglected or mentioned in passing without due justice being paid. For these omissions I apologize in advance.

\section{AQUATION AND ANATION OR SUBSTITUTION}

There are at least two very clear examples of limiting dissociative processes. One involves activation by $\mathrm{CN}^{-}$in systems like $\left[\mathrm{Co}^{\mathrm{lll}}(\mathrm{CN})_{5} \mathrm{X}\right]^{\mathrm{n}-}\left(\mathrm{X}=\mathrm{H}_{2} \mathrm{O}\right.$, $\left.\mathrm{NH}_{3}, \mathrm{P}_{4}, \mathrm{~N}_{3}^{-}, \mathrm{I}^{-}, \mathrm{Br}^{-}\right)^{1}$ for reactions of the type $\left[\mathrm{Co}(\mathrm{CN})_{5} \mathrm{X}\right]^{3-}+\mathrm{H}_{2} \mathrm{O} \rightarrow$ $\left[\mathrm{Co}(\mathrm{CN})_{5}\right]^{2-}+\mathrm{X}^{-}+\mathrm{H}_{2} \mathrm{O} \rightarrow\left[\mathrm{Co}(\mathrm{CN})_{5} \mathrm{OH}_{2}\right]^{2-}+\mathrm{X}^{-1}$ and the other involves activation by $\mathrm{SO}_{3}^{2-}$ in related processes for systems like trans$\left[\mathrm{Co}^{\mathrm{III}}\left(\mathrm{NH}_{3}\right) \mathrm{SO}_{3} \mathrm{X}\right]^{\mathrm{n}+2}$, trans- $\left[\mathrm{Co}(\mathrm{CN})_{4} \mathrm{SO}_{3} \mathrm{X}\right]^{\mathrm{n}-}$ and trans- $\left[\mathrm{Co}(\mathrm{en})_{2} \mathrm{SO}_{2^{-}}\right.$ 
$\mathrm{X}]^{\mathrm{n}+}\left(\mathrm{X}=\mathrm{CN}^{-}, \mathrm{NCS}^{-}, \mathrm{NH}_{3}, \mathrm{HO}^{-}, \mathrm{NO}_{2}^{-}, \mathrm{N}_{3}^{-}, \mathrm{SO}_{3}^{2-}\right)^{3}$. These reactions are well established as involving intermediates of reduced coordination number. Also the competition properties of the latter species for various nucleophiles have served to characterize, at least in part, the intermediates. Moreover, since the trans sulphito species all react to give trans products it might be inferred that the structure of the intermediate is close to that of a square pyramid. It is also likely that intermediates of reduced coordination number occur in some $\mathrm{Co}^{\mathrm{III}}$-dimethylglyoxime systems ${ }^{1,4,5}$, in some porphyrin systems ${ }^{6}$, in some $\mathrm{Co}^{\text {III }}$-alkyl Schiffs base type complexes ${ }^{7}$ and for the $\left[\mathrm{RhCl}_{5} \mathrm{OH}_{2}\right]^{2-}$ water exchange ${ }^{8}$. An excellent review ${ }^{1}$ of this area has appeared recently and the subject will not be pursued at length. However, one interesting question which remains unanswered is the stereochemistry of the $\left[\mathrm{Co}(\mathrm{CN})_{5}\right]^{2-}$ intermediate, and ${ }^{13} \mathrm{C}$ labelling of $\mathrm{CN}^{-}$trans to the leaving group might resolve this problem.

In most substitution processes however, the characterization is less clear. For metal ions usually classified as labile there is a substantial body of information on water exchange ${ }^{9,10}$ and substitution by neutral and anionic species derived from relaxation techniques ${ }^{11}$. These topics have been reviewed frequently and will not be pursued here other than to say that the rate of entry of the substituting species is not very different from the water exchange rate, (usually within a factor of 5). Some of the rate constants are evaluated using a calculated association constant so that there is some flexibility in the derived value. However, it is clear that the rate usually depends rather slightly on the entering group and that the process of substitution is primarily dissociative. It is much more doubtful if a limiting rate is involved.

If we now look at the kinetically more inert or robust species then there is less information in terms of the variety of metals and complex species, but a similar pattern emerges. For example, the water exchange rates have been measured for the species $\left[\left(\mathrm{NH}_{3}\right)_{5} \mathrm{MOH}_{2}\right]^{3+}\left(\mathrm{M}=\mathrm{Co}^{\mathrm{III} 12}, \mathrm{Cr}^{\mathrm{III} 13}, \mathrm{Rh}^{\mathrm{III} 15}\right.$, $\left.\mathrm{Ir}^{\mathrm{III}}{ }^{16}\right)$ and the rates of anion entry ${ }^{14,17,18}$ do not differ greatly from each other for a particular metal ion. Also many are close to the water exchange rate, but whether they exceed or are less than the water exchange rate largely depends on the association constant used to calculate anion entry.

If we look now at aquation of species like $\left[\left(\mathrm{NH}_{3}\right)_{5} \mathrm{MX}\right]^{2+}(\mathrm{X}=\mathrm{Cl}, \mathrm{Br}$, $\mathrm{NO}_{3}$, etc.) some pointed facts emerge. Assuming the mechanism

$$
\begin{aligned}
& {\left[\left(\mathrm{NH}_{3}\right)_{5} \mathrm{CoX}\right]^{2+} \rightleftarrows\left[\left(\mathrm{NH}_{3}\right)_{5} \mathrm{Co}\right]^{3+}+\mathrm{X}^{-}} \\
& {\left[\left(\mathrm{NH}_{3}\right)_{5} \mathrm{Co}\right]^{3+}+\mathrm{H}_{2} \mathrm{O} \rightleftarrows\left[\left(\mathrm{NH}_{3}\right)_{5} \mathrm{CoOH}_{2}\right]^{3+}}
\end{aligned}
$$

exists for aquation of the $\mathrm{Co}^{\mathrm{III}}$ complex, it follows that competitors other than water should be captured if they are present in solution. However, at least one experiment ${ }^{19}$ has shown that other competitors are not captured except by subsequent reaction of the aquo complex formed. Some preferential bond making by water would accommodate this result, although an intermediate of reduced coordination number which greatly preferred water to the anions would also suit.

Evidence for theimportance of bond breaking in the aquation process comes from the dependence of the rate of loss of anion on the charge of the complex ${ }^{20}$. More sophisticated arguments ${ }^{21,22}$ derived from linear free energy relationships lead to the same conclusion but do not exclude some bond making by 


\section{OCTAHEDRAL SUBSTITUTION MECHANISMS}

the solvent water. Additional support ${ }^{23}$ comes from the volumes of activation $\Delta V^{\ddagger}$, which indicate largely dissociative character in the process but not exclusively so. There is an apparent dichotomy in the conclusions and an obvious need to establish the properties of the five-coordinate intermediate so that the limiting situation can be characterized at one end of the scale at least.

What happens when aquation is induced under conditions where the leaving group is especially good? The following processes fit this description.

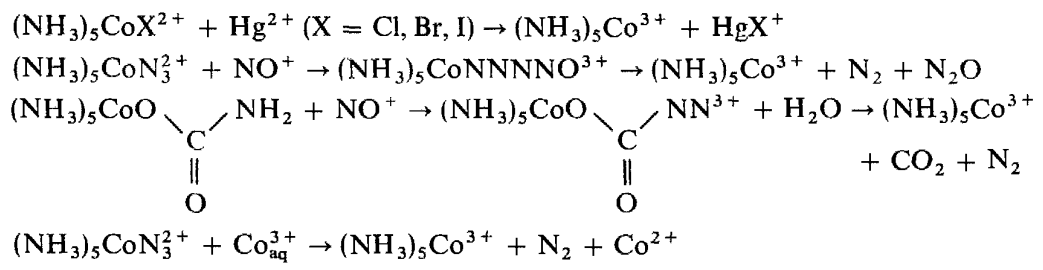

(Ref. 27)

In these reactions anions such as $\mathrm{Cl}^{-}, \mathrm{NO}_{3}^{-}, \mathrm{HSO}_{4}^{-}, \mathrm{Br}^{-}, \mathrm{NCS}^{-}, \mathrm{F}^{-}$compete along with $\mathrm{H}_{2} \mathrm{O}^{16}$ and $\mathrm{H}_{2} \mathrm{O}^{18}$ for the intermediate and aquo and anated complexes are formed simultaneously. Moreover in three of these instances, where the competition ratio can be clearly evaluated, the same competition ratio for the different leaving groups for separate anions is observed. The inference from this common result, is that a common intermediate has been generated. Recently another example of this property has been observed which is complicated by some additional reactions. The complex $\left[\left(\mathrm{NH}_{3}\right)_{5}-\right.$ $\mathrm{CoNCO}]\left(\mathrm{ClO}_{4}\right)_{2}{ }^{28}$ in aqueous acid undergoes three reactions ${ }^{29}$ as follows:

$$
\begin{aligned}
& {\left[\left(\mathrm{NH}_{3}\right)_{5} \mathrm{CoNCO}\right]^{2+}+\mathrm{H}_{3} \mathrm{O}^{+} \stackrel{k_{\mathrm{H}_{3} \mathrm{O}^{+}}}{\longrightarrow}\left[\left(\mathrm{NH}_{3}\right)_{5} \mathrm{CoNH}_{2} \backslash_{\mathrm{C}^{\prime}}, \mathrm{OH}\right]^{3+}}
\end{aligned}
$$

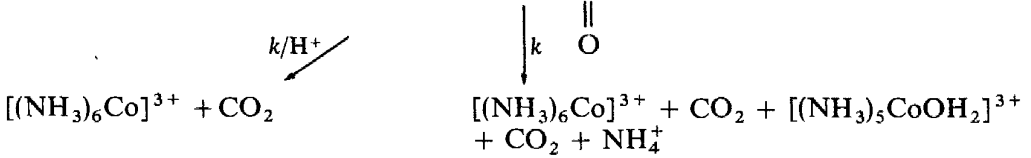

Firstly the cyanato complex is hydrated and then two paths occur for the decay of the labile $\mathrm{N}$-bonded carbamato complex, one to give hexaammine solely, the other to give both hexaammine and pentaammine aquo complex. This behaviour parallels that for the corresponding rhodium complex except that production of the aquo complex was not observed ${ }^{30}$. Nitrosation of the labile $\mathrm{Co}^{\mathrm{III}}$-carbamato complex ${ }^{29}$ also occurs eliminating $\mathrm{CO}_{2}$ and $\mathrm{N}_{2}$ and preliminary competition results indicate the competition ratios are close to those described above 26,27 .

Another process recently examined is the hydrolysis of the $\left[\left(\mathrm{NH}_{3}\right)_{5} \mathrm{Co}-\right.$ $\left.\mathrm{OH}-\mathrm{Co}\left(\mathrm{NH}_{3}\right)_{5}\right]^{5+}$ ion $^{31,32}$ which has a rate law, $k_{\mathrm{obs}}=k+k^{\prime}\left[\mathrm{H}^{+}\right]$ $\left(k \approx 6 \times 10^{-3} \mathrm{~s}^{-1}, k^{\prime}=0.3 \mathrm{M}^{-1} \mathrm{~s}^{-1}\right.$ at $\left.25^{\circ} \mathrm{C}\right)$. In $1 \mathrm{M} \mathrm{H}^{+}$the reaction occurs almost solely by the second path ${ }^{32}$ with a half-life of $\approx 2 \mathrm{~s}$ and in the presence of anionslikeCl- ${ }^{-}, \mathrm{HSO}_{3}$ and $\mathrm{CH}_{3} \mathrm{SO}_{3}^{-}$competition is observed simultaneously with the production of the aquo complex. However the overall picture is 


\section{A. M. SARGESON}

totally different from the previous chemistry for now we have a $6^{+}$ion as the reactive species. Ion pair formation is likely to be significant and in the range $1.0 \mathrm{M} \mathrm{H}_{2} \mathrm{SO}_{4}$ to $0.1 \mathrm{M} \mathrm{H}_{2} \mathrm{SO}_{4}$ the amount of sulphato complex produced is constant $(\approx 37 \text { per cent })^{32}$. Since only half the total cobalt can form as the intermediate $\left(\mathrm{NH}_{3}\right)_{5} \mathrm{Co}^{3+}, \approx 75$ per cent of this species is captured by the anion. While this story is not as revealing as the previous examples, in terms of contributing to the common property, it displays the competition process and supports the case that ion pairs are not especially important in the previous examples, since no saturation effects are observed and the amount of competition is linearly dependent on the competitor concentration.

It is evident from the foregoing studies that the intermediates do compete for a number of species in solution once they are formed, in contrast to the apparent lack of competition during the spontaneous aquation of anions such as $\mathrm{Cl}^{-}, \mathrm{Br}^{-}, \mathrm{I}^{-}, \mathrm{NO}_{3}^{-}$. Additional evidence for the generation of fivecoordinate intermediates by these induced aquation paths comes from the stereochemical course of the processes. In systems like $\Lambda-\left[\mathrm{Co}(\mathrm{en})_{2} \mathrm{ClN}_{3}\right]^{+}+$ $\mathrm{Hg}^{2+33,34}$ and $\Lambda$ - $\left[\mathrm{Co}(\mathrm{en})_{2}\left(\mathrm{~N}_{3}\right)_{2}\right]^{+}+\mathrm{NO}^{+}$, where $\mathrm{Cl}^{-}$is induced to leave in one instance and $\mathrm{N}_{3}^{-}$in the other, the azido-aquo products are constant $(\approx 80$ per cent $\Lambda$ and 20 per cent trans $)$ and a common $\left[\mathrm{Co}(\mathrm{en})_{2} \mathrm{~N}_{3}\right]^{2+}$ intermediate is inferred. This result is reproduced for both the cis and trans pairs, and for the induced aquations of the cis and trans chloro-aquo and azido-aquo ions ${ }^{33-35}$. Moreover, the results for both cis and trans isomers are quite different from that for the spontaneous aquation in the examples given above. Usually the cis isomers aquate with retention of cis configuration (except cis- $\left[\mathrm{Co}(\mathrm{en})_{2} \mathrm{Br}_{2}\right]^{+36}$ ) and the trans isomers frequently give rearrangement. It should be pointed out however that although cis gives cis commonly, it has not been shown that $\Lambda$-cis $\rightarrow \Lambda$-cis except in a few instances, one of which is the $\Lambda$ - $\left[\mathrm{Co}(\mathrm{en})_{2} \mathrm{ClN}_{3}\right]^{+}$ion $^{34}$.

The pentaamine type complexes are not very revealing in this context since both induced and spontaneous aquation give retention of configuration. This conclusion must be qualified by the possibility that retention/rearrangement of $99 / 1 v .999 / 1$ would be difficult to detect by the present methods. Despite these restrictions the stereochemistry of the reaction path commonly identifies the difference between the spontaneous and induced aquation.

\section{PROPERTIES OF THE INTERMEDIATES}

The competition experiments ${ }^{26,27,29}$ show that there is little discrimination between the anions for the intermediate and that the anions $\left(\mathrm{Cl}^{-}, \mathrm{Br}^{-}, \mathrm{NO}_{3}^{-}\right.$, $\mathrm{F}^{-}, \mathrm{HSO}_{4}^{-}, \mathrm{NCS}^{-}$) are much better competitors than water, molecule for molecule $(5-20 \times)$. The lack of discrimination indicates that the $\left[\mathrm{Co}\left(\mathrm{NH}_{3}\right)_{5}\right]^{3+}$ intermediate is especially reactive. Little activation is required and the anions do not get a chance to exert their nucleophilic characteristics. The other feature of note here is that the ions which are solvated best, e.g. $\mathrm{F}^{-}$are the poorest competitors, whereas those solvated least, e.g. $\mathrm{NO}_{3}^{-}$compete well for water. The implication of these results is that the lifetime of the intermediate is very short and possibly that the rate-determining step is the abstraction of the competitor from the solvent sheath. In this context we know for example that using $\mathrm{NCS}^{-}$as competitor for water the $\mathrm{S}$ atom is captured more readily 
than the $\mathrm{N}$ atom $(\approx 4 \times)^{37}$. Here $\mathrm{N}$ is $\mathrm{H}$-bonded to the solvent molecules and $\mathrm{S}$ less so, if at all.

The structures of the intermediates might be inferred from the stereochemical results in some instances. For example, all the pentaammine type complexes react with retention of configuration implying that the geometry of this species is not greatly different from a square pyramid ${ }^{38}$; possibly the Co atom is raised slightly above the basal plane. Certainly for $\left[\left(\mathrm{NH}_{3}\right)_{4}\left(\mathrm{ND}_{3}\right) \mathrm{Co}\right]^{3+}$ a regular trigonal bipyramid is excluded ${ }^{38}$.

For the induced reactions involving two cis anions in the structure, the rearrangement can be accommodated by structures of the form<smiles>[X]C12N3CN1N2CN3</smiles>

where the group enters at the edges of the trigonal plane to give $\Lambda$-cis from two edges and trans from the other. It may be significant that in the few cases tested so far no racemization has been observed in the products. Also when one trigonal edge is blocked with a chelate, e.g.<smiles>[X]C12NN3CCN1CNC32[X]</smiles>

no trans or $\beta$-product appears ${ }^{39}$. The supposed trigonal bipyramidal species might be stabilized by $d_{\pi}-p_{\pi}$ overlap between filled orbitals on the anionic ligand with the empty d-orbitals on the metal ion ${ }^{40}$.

Stabilization of the intermediate by changing the ligand field is a possibility which has recently been realized and a low-spin five-coordinate square pyramidal species has been isolated and characterized by $\mathrm{x}$-ray crystallography ${ }^{41}$,<smiles></smiles>

Similar compounds, e.g.

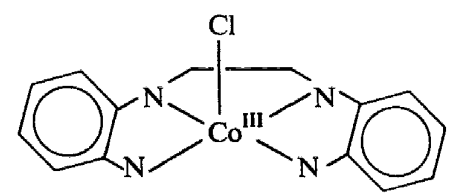

which are characterized by two unpaired electrons at room temperature have also been isolated ${ }^{42}$. Even in pyridine the equilibrium

$$
\begin{aligned}
& {[\mathrm{Co}-\mathrm{L}-\mathrm{Cl}-\mathrm{py}] \rightleftarrows[\mathrm{Co}-\mathrm{L}-\mathrm{Cl}]+\text { py }} \\
& \mathrm{L}=\text { bis(benzildeneamino-1,2-propane) }
\end{aligned}
$$




\section{A. M. SARGESON}

is only 75-80 per cent towards the six-coordinate species. In a crude picture of the bonding scheme it seems that the $\mathrm{d}_{\mathrm{z}^{2}}$ and $\mathrm{d}_{\mathrm{xy}}$ levels are now close enough so that both are partly populated. These studies and the previous chemistry reflect the two extremes for reactivity and stability of five-coordinate cobalt(III) complexes, largely dominated by the ligand fields involved in the two cases. An appropriate analogy might be found in the characteristics of $\left(\mathrm{CH}_{3}\right)_{3} \mathrm{C}^{+}$and $(\mathrm{Ph})_{3} \mathrm{C}^{+}$and more discrimination for nucleophiles should be observed as the lifetime of the intermediate is extended.

\section{BASE HYDROLYSIS}

The overall process is exemplified by the reaction between a cobalt(III) pentaammine species and $\mathrm{OH}^{-}$ion

$$
\left(\mathrm{NH}_{3}\right)_{5} \mathrm{CoX}^{2+}+\mathrm{OH}^{-} \rightarrow\left(\mathrm{NH}_{3}\right)_{5} \mathrm{CoOH}^{2+}+\mathrm{X}^{-}
$$

The same process appears for related $\mathrm{Rh}^{\mathrm{III}}, \mathrm{Ir}^{\mathrm{III}}, \mathrm{Ru}^{\mathrm{III}}$ and $\mathrm{Cr}^{\mathrm{III}}$ ions at least, and although there are less data for these metals what exists appears to be similar in principle to that observed for the cobalt(III) species. Commonly the rate law has the form, $v=k[$ complex $]\left[\mathrm{OH}^{-}\right]$and the reaction is usually associated with ammine complexes which have at least one dissociable proton on a nitrogen atom. However other ligands with dissociable protons also show that same phenomenon, e.g. $\mathrm{OH}_{2}{ }^{44}$. In the absence of such a proton (at least for $\mathrm{Co}^{\text {III }}$ complexes) different properties are observed.

To date the reactions appear to occur largely with retention of configuration for all the complexes except those of $\mathrm{Co}^{\text {III }}$, which are characterized by substantial rearrangement. Also a wide range of leaving groups has been studied, e.g. $\mathrm{I}^{-}, \mathrm{Br}^{-}, \mathrm{Cl}^{-}, \mathrm{F}^{-}, \mathrm{SO}_{4}^{2-}, \mathrm{NCS}^{-}, \mathrm{NO}_{3}^{-},{ }^{-} \mathrm{OOCR},{ }^{-} \mathrm{SO}_{3} \mathrm{R}, \mathrm{NO}_{2}^{-}$and $\mathrm{N}_{3}^{-}$ with rate constants varying over at least a range of $10^{12}$. Primarily cobalt(III) complexes will be used as examples because most data exist for these species and because the stereochemical changes are an additional tool to probe the reaction.

Since the subject has been reviewed frequently ${ }^{45-47}$, I need not pursue all the mechanistic proposals. It suffices to say that the evidence at the moment is compelling for a dissociative process of the conjugate base, as follows:

$$
\begin{gathered}
{\left[\left(\mathrm{NH}_{3}\right)_{5} \mathrm{CoX}\right]^{2+}+\mathrm{OH}^{-} \frac{k_{1}}{k_{2}}\left[\left(\mathrm{NH}_{3}\right)_{4} \mathrm{NH}_{2} \mathrm{CoX}\right]^{+}+\mathrm{H}_{2} \mathrm{O}} \\
{\left[\left(\mathrm{k}_{3}\right.\right.} \\
\left.\left.\left[\left(\mathrm{NH}_{3}\right)_{4}\right)_{5} \mathrm{CoOH}\right]^{2+} \mathrm{NH}_{2} \mathrm{Co}\right]^{2+}+\mathrm{X}^{-} \\
{\left[\mathrm{H}_{2} \mathrm{O} \mathrm{Y}^{-2}+\mathrm{H}^{+}\right. \text {fast }}
\end{gathered}
$$

The mechanism has several areas of interest which deserve special attention.

\section{(a) Rate law}

The situation described cannot be solved for the general case except by numerical integration methods ${ }^{48}$, but there are some limiting cases which allow an algebraic solution.

(i) If $k_{1} \ll k_{2}$ and $k_{3}$ then deprotonation is the rate-limiting step and the rate should be $k_{\mathrm{obs}}=k_{1}\left[\mathrm{OH}^{-}\right]$. It has been asserted that trans-[Cocyclam $\left.\mathrm{Cl}_{2}\right]^{+}$ hydrolyses to $[\mathrm{Cocyclam}(\mathrm{OH})(\mathrm{Cl})]^{+}\left(67,000 \mathrm{M}^{-1} \mathrm{~s}^{-1}, 25^{\circ} \mathrm{C}\right)$ by this latter route since only slightly more than one proton has exchanged in the product ${ }^{45}$. 
These results indicate that the reprotonation rate is comparable to the rate of dissociation of $\mathrm{Cl}^{-}$ion and to the deprotonation rate. If this is so a dissociation constant $\left(K_{\mathrm{a}}\right)$ of $\approx 10^{-14}$ is indicated, instead of $\approx 10^{-16}$ which has been estimated from several sources for $N$-methyl substituted ethylenediamine and for ammonia complexes ${ }^{49,50}$.

(ii) If $k_{1}<k_{2} \gg k_{3}$ then proton exchange is established rapidly and a small concentration of the deprotonated reactant exists. The steady-state approximation applied to this situation yields a rate law of the form

$$
k_{\mathrm{obs}}=\frac{k_{1} k_{3}\left[\mathrm{OH}^{-}\right]}{k_{2}+k_{3}}
$$

Commonly in the $\mathrm{Co}^{\mathrm{III}}$ complexes $k_{3} \ll k_{2}$ so that the rate law reduces to

$$
\begin{aligned}
k_{\mathrm{obs}} & =\frac{k_{1}}{k_{2}} \times k_{3}\left[\mathrm{OH}^{-}\right] \\
& =\frac{K_{\mathrm{a}}}{K_{\mathrm{w}}} \times k_{3}
\end{aligned}
$$

(iii) Finally if the deprotonation is considered as a pre-equilibrium then the derived rate law takes the form

$$
k_{\mathrm{obs}}=\frac{k K\left[\mathrm{OH}^{-}\right]}{1+K\left[\mathrm{OH}^{-}\right]}
$$

Not infrequently deprotonation is much faster than hydrolysis and the rate law observed up to $1 \mathrm{M} \mathrm{OH}{ }^{-}$for $\left[\left(\mathrm{NH}_{3}\right)_{5} \mathrm{CoCl}\right]^{2+}$ is $k_{\text {obs }}=k^{\prime}\left[\mathrm{OH}^{-}\right]$. Clearly $k^{\prime}=k K$ and the equilibrium constant $K\left(=K_{\mathrm{a}} K_{\mathrm{w}}^{-1}=K_{\mathrm{b}}^{-1}\right)$ must be small, $<0.05$, since $K\left[\mathrm{OH}^{-}\right]$is not significant in the denominator ${ }^{51}$ $\left(K_{\mathrm{a}}<10^{-16}\right)$. The possibility that significant concentrations of the conjugate base arise when the amine is more acidic is realized for $c i s-\left[\mathrm{Co}(\mathrm{en})_{2} \mathrm{NH}_{2}-\right.$ $\mathrm{PhCl}]^{2+52-54}$. The first-order dependence on $\left[\mathrm{OH}^{-}\right]$vanishes in the vicinity of $\mathrm{pH} 10$ and commences to approach a limiting rate. For the aniline complex ${ }^{54}$ rate constants at different $\mathrm{pH}$ show a marked deviation from a first-order dependence on $\mathrm{OH}^{-}$at high values (Table 1). Also the different rate constants at essentially constant $\mathrm{pH}$ and varying buffer concentrations show that general base hydrolysis is involved. The $\mathrm{p} K_{\mathrm{a}}$ for coordinated aniline calculated from these data was $\approx 10$, which agrees with the estimates from other sources $^{52,53}$.

Table 1. Base hydrolysis rate constants $\dagger$ for cis$\left[\mathrm{Co}(\mathrm{en})_{2} \mathrm{NH}_{2} \mathrm{PhCl}\right] \mathrm{Cl}_{2}$ at $25^{\circ} \mathrm{C}, \mu=1 \mathrm{M}$

\begin{tabular}{rlcl}
\hline $\mathrm{pH}$ & Buffer $(\mathrm{M})$ & $k_{\text {obs }}\left(\mathrm{s}^{-1}\right)$ & $k_{\text {obs }} / \mathrm{OH}^{-}\left(\mathrm{M}^{-1} \mathrm{~s}^{-1}\right)$ \\
\hline 8.25 & $0.1 \ddagger$ & 0.041 & $2.3 \times 10^{4}$ \\
9.19 & $0.1 \S$ & 0.24 & $1.6 \times 10^{4}$ \\
9.21 & 0.2 & 0.29 & \\
10.22 & $0.1 \S$ & 1.4 & $0.84 \times 10^{4}$ \\
10.27 & 0.2 & 1.7 & \\
\hline
\end{tabular}

+ Data collected with stopped flow reactor for $[\mathrm{Co}]=2 \times 10^{-3} \mathrm{M}$

$\ddagger$ Triethanolamine $\cdot \mathrm{HClO}_{4}, \mu=1 \mathrm{M}\left(\mathrm{NaClO}_{4}\right)$

\& Diethanolamine $\cdot \mathrm{HClO}_{4}, \mu=1 \mathrm{M}\left(\mathrm{NaClO}_{4}\right)$ 


\section{A. M. SARGESON}

The marked increase in second-order rate constant for this species relative to cis- $\left[\mathrm{Co}(\mathrm{en})_{2} \mathrm{NH}_{3} \mathrm{Cl}\right]^{2+}$, under the same conditions $\left(3.3 \mathrm{M}^{-1} \mathrm{~s}^{-1}\right)$, can be accounted for largely by the acidity of coordinated aniline. It also pinpoints the position of deprotonation for this complex. As the protons become more acidic so general base catalysis ${ }^{45,52,54}$ appears in addition to $\mathrm{OH}^{-}$catalysisa characteristic of conjugate base mechanisms. Clearly there is now a range of behaviour extending from proton exchange as the rate-limiting step to the actual observation of the deprotonated reactant.

\section{(b) Deprotonation}

A vexing question still is which deprotonated species is the reactive entity ${ }^{55}$. Clearly for species like trans- $\left[\mathrm{Co}(\mathrm{en})_{2} \mathrm{Cl}_{2}\right]^{+}$the molecule must be deprotonated cis to the leaving group, but in the cis isomer the question of whether $\mathrm{H}^{+}$is removed cis or trans to $\mathrm{Cl}^{-}$remains unanswered. In this latter compound, $\mathrm{OH}^{-}$-catalysed $\mathrm{H}^{+}$exchange is $\approx 10^{2}$ faster for the $\mathrm{NH}_{2}^{-}$group trans to $\mathrm{Cl}^{-}$than for the species cis $(\mathrm{H}$-exchange rate is used as a rough guide to the acidity, where $\mathrm{p} K_{\mathrm{a}}>14$ ). However, this does not require the trans deprotonated reactant to be the reactive species. The problem could be illuminated with two isomers containing one labile N-proton which can be either cis or trans to the leaving group. Alternatively if the protons cis and trans to the leaving group exchange at vastly different rates and if the cis protons exchange more slowly than hydrolysis of the leaving group, a clear answer is obtained. This latter situation is being examined with the $[\mathrm{Co}-$ (trenen) $\left.\mathrm{SO}_{3} \mathrm{CF}_{3}\right]^{2+}$ ion, where $\mathrm{CF}_{3} \mathrm{SO}_{3}^{-}$is an excellent leaving group and there is $>10^{4}$-fold difference between the acidity of the proton trans to the leav-

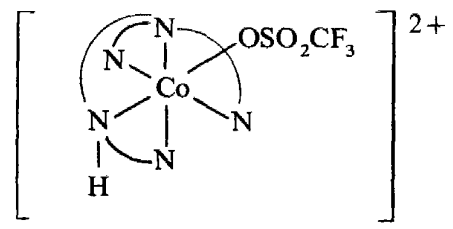

ing group and the next most acidic proton, which must be $\mathrm{cis}^{56}$. Other evidence which impinges on this question comes from $\mathrm{Rh}^{\mathrm{III}}$ chemistry where [Rh(tren) $\left.\mathrm{Cl}_{2}\right]^{+}$shows only one $\mathrm{Cl}^{-}$released by the base hydrolysis path and it is asserted that $\mathrm{Cl}^{-}$trans to the tertiary $\mathrm{N}$-centre is retained on the basis that if cis deprotonation was the effective intermediate then both $\mathrm{Cl}^{-}$ions should be hydrolysed ${ }^{57}$. A similar result was obtained with cis- and trans-[Rh(en) ${ }_{2}$ (py)Cl ${ }^{2+57}$. It is conceivable, but unlikely, that $\mathrm{Co}^{\mathrm{III}}$ and $\mathrm{Rh}^{\mathrm{III}}$ are so diverse that cis deprotonation is effective in one instance while trans is effective in the other. It is more likely that both cis and trans deprotonated species can be effective reactants, but more examples are needed where the relative reactivity of the different species can be evaluated. Some additional evidence bearing on these issues will appear later.

\section{(c) Activation of the deprotonated reactant}

There is a wide variety of leaving groups for $\mathrm{Co}^{\mathrm{III}}$ complexes, e.g. $\mathrm{NO}_{2}^{-}<$ $\mathrm{N}_{3}^{-} \approx \mathrm{NCS}^{-}, \approx-\mathrm{OOCR}^{-}<\mathrm{SCN}^{-}, \approx \mathrm{Cl}^{-},<\mathrm{Br}^{-},<\mathrm{I}^{-},<\mathrm{NO}_{3}^{-} \approx$ $\mathrm{CH}_{3} \mathrm{SO}_{3}^{-}<\mathrm{NO}_{2} \mathrm{PhSO}_{3}^{-}<\mathrm{CF}_{3} \mathrm{SO}_{3}^{-}$(arranged in order of lability) which 
cover rate constants from $\approx 10^{-6} \mathrm{M}^{-1} \mathrm{~s}^{-1}$ to $10^{6} \mathrm{M}^{-1} \mathrm{~s}^{-1}$ at $25^{\circ} \mathrm{C}$ for $\left[\left(\mathrm{NH}_{3}\right)_{5}\right.$ $\mathrm{CoX}]^{2+}$ complexes. Moreover the first-order rate constant for the deprotonated reactant must be greater than the overall hydrolysis rate constant $\left(>10^{2}\right)$ since the $\mathrm{p} K_{\mathrm{a}}$ 's for the complexes cited above exceed 14. The rapid reaction has been attributed to the inductive effect of the coordinated amide ion by comparison with $\mathrm{Cl}^{-}$and $\mathrm{OH}^{-}$on the basis that $\mathrm{Cl}^{-}<\mathrm{OH}^{-}<\mathrm{NH}_{2}^{-}$. Evidence for the proposal was adduced from the hydrolysis rates for cis- $\left[\mathrm{Co}(\mathrm{en})_{2} \mathrm{Cl}_{2}\right]^{+}<$cis- $\left[\mathrm{Co}(\mathrm{en})_{2} \mathrm{ClOH}\right]^{+} \ll c i s-\left[\mathrm{Co}(\mathrm{en}){ }_{2} \mathrm{NH}_{2} \mathrm{Cl}\right]^{+}$(or the deprotonated en analogue $)^{58}$. Another attractive and much quoted possibility is that the lone pair of electrons on the amido group can assist a group to leave. It is postulated that this process finally stabilizes a five-coordinate intermediate through a $\pi$-interaction between filled orbitals on the $\mathrm{N}$-centre with empty d-orbitals on the metal ion ${ }^{58}$. Which of these effects dominates the mechanism is not clearly established although there is some evidence which mitigates $\pi$-stabilization. For bulky amine and some multidentate amine complexes steric effects play a large part in accelerating the reaction rate and one of these effects will be discussed shortly. However, until something is known about the concentration of the possible deprotonated reactants and their reactivities it seems premature to discuss the electronic role of the substituents.

\section{(d) Intermediates}

The most compelling evidence for the existence of an intermediate of reduced coordination number comes from the competition properties of these species ${ }^{37,59-62}$. For complexes of the type $\left[\left(\mathrm{NH}_{3}\right)_{5} \mathrm{CoX}\right]^{2+}$, for $\mathrm{X}=\mathrm{Cl}^{-}$, $\mathrm{Br}^{-}, \mathrm{I}^{-}, \mathrm{NO}_{3}^{-}, \mathrm{SCN}^{-}, \mathrm{CH}_{3} \mathrm{SO}_{3}^{-}, \mathrm{NO}_{2} \mathrm{PhSO}_{3}^{-}$and $\mathrm{CF}_{3} \mathrm{SO}_{3}^{-}$, a common result has been obtained for competition by isotopes of water $\mathrm{H}_{2} \mathrm{O}^{16}$ \% $\mathrm{H}_{2} \mathrm{O}^{18}$ and for anions such as $\mathrm{N}_{3}^{-}, \mathrm{NCS}^{-}$, and $\mathrm{NO}_{2}^{-} v \mathrm{H}_{2} \mathrm{O}^{59,60}$. These studies also indicate that $\mathrm{H}_{2} \mathrm{O}$ is the competitor, not $\mathrm{OH}^{-59,60}$. A common result was also obtained for different leaving groups when the stereochemistry of the products from trans $=\left[\left(\mathrm{NH}_{3}\right)_{4}\left({ }^{15} \mathrm{NH}_{3}\right) \mathrm{CoX}\right]^{2+}\left(\mathrm{X}=\mathrm{Cl}, \mathrm{Br}, \mathrm{NO}_{3}{ }^{63}\right)$ and cis- and trans- $\left[(\mathrm{en})_{2} \mathrm{NH}_{3} \mathrm{CoX}\right]^{2+}\left(\mathrm{X}=\mathrm{Cl}, \mathrm{Br}, \mathrm{NO}_{3}\right.$, and $\left.\mathrm{SCN}^{-}\right)$was examined $^{61}$. For the latter system, not only was the stereochemistry of the hydroxo product constant, but when the experiments were carried out in the presence of $\mathrm{N}_{3}^{-}$ion both the competition ratio azido/hydroxo and the stereochemistry of the azido products for different leaving groups were constant. Moreover, this property appears to hold for quite a wide range of leaving groups ${ }^{64}$, within the errors of the experiments. Entry of anion coincides with hydrolysis and there does not appear to be a term involving the anion in the rate law $^{37}$. This observation militates against the possibility that there is an associative conjugate base mechanism $\left(\mathrm{S}_{\mathrm{N}} 2 \mathrm{CB}\right)$ where the anion and water compete for entry before the leaving group departs. It has been argued of course that the common competition result from the differing leaving groups also is inconsistent with this proposal. The variation in size and electronic properties of the leaving groups would be expected to give variations in competition properties and in the stereochemistry of the products if an associative process were involved. However, probably the strongest evidence against an associative mechanism is to be found in the reactions of sterically hindered molecules. For example, $\left[\mathrm{Co}\left(\mathrm{NH}_{2} \mathrm{CH}_{3}\right)_{5} \mathrm{Cl}\right]^{2+}$ 
and $\left[\mathrm{Co}\left(\mathrm{NH}_{2} \mathrm{CH}^{-} \mathrm{CH}_{3}\right)_{5} \mathrm{H}_{5}{ }^{2}\right]^{2+}$ hydrolyse $\approx 10^{4}-10^{5}$ times faster than $\left[\mathrm{Co}\left(\mathrm{NH}_{3}\right)_{5} \mathrm{Cl}\right]^{2+}$ in the presence of base under the same conditions ${ }^{65}$. The $\mathrm{N}$-proton acidity remains largely unaltered and the acceleration is ascribed to steric hindrance which is relieved in the transition state by substantial stretching of the $\mathrm{Co}-\mathrm{Cl}$ bond. The structure of the ground state for $\left[\mathrm{Co}\left(\mathrm{NH}_{2}-\right.\right.$ $\left.\left.\mathrm{CH}_{3}\right)_{5} \mathrm{Cl}\right]^{2+}$ has been studied in a crystal and all the $\mathrm{Co}-\mathrm{N}-\mathrm{C}$ angles are deformed to $122-124^{\circ}$ compared with normal tetrahedral angles $\left(\approx 109^{\circ}\right)^{66}$. The observed geometry is also consistent with that calculated from a general force field and energy minimization approach ${ }^{67}$ which appears to eliminate any contention that the deformation might be due to crystal forces. Clearly an acceleration in rate could not be accommodated if an associative process was involved. Any increase in coordination number must compound the steric problems and make the transition state less accessible.

Preliminary studies also indicate that ion pairing is not important and more recent results show that situations where the deprotonated reactant has zero charge and where the intermediate has zero charge both show extensive competition for anion ${ }^{68}$. The common competition ratiofor different leaving groups also implies that only one of the deprotonated reactants is involved. The possibility that a parent complex moiety, with different leaving groups, has a constant ratio between the acidities for two sites of deprotonation and a constant ratio between the reactivities for those two deprotonated reactants seems highly unlikely. Alternatively the possibility that the constant competition properties arise from accidental cancellation of these factors also seems remote. However, if only one deprotonated reactant dominates the mechanism then the common properties arise logically.

\section{(e) Properties of the intermediate}

There appears to be little discrimination between the nucleophiles $\mathrm{N}_{3}^{-}$, $\mathrm{NO}_{2}^{-}, \mathrm{OAc}^{-}, \mathrm{NCS}^{-}, \mathrm{HOCH}_{3}, \mathrm{NH}_{3}$ and $\mathrm{H}_{2} \mathrm{O}^{69}$ for the intermediate $\left[\left(\mathrm{NH}_{3}\right)_{4} \mathrm{NH}_{2} \mathrm{Co}\right]^{2+}$. Water and methanol are better $(\approx 10 \times)$ than ammonia and the anions are $2-5$ times better than water on an equimolar scale. It is deduced, therefore, that the intermediate is especially reactive and that the nucleophile does not get much chance to exert itself. It is possible that abstraction of the competitor from the solvent sheath might be rate determining for this part of the process. Some evidence for such a proposal is adduced from the fact that the best competitors are those which are least solvated or involved in the solvent structure. It follows that intermediates of this type require little activation and $E_{\mathrm{a}}$ is probably close to the temperature dependence of water molecule diffusion, i.e. $\approx 2 \mathrm{kcal} \mathrm{mol}^{-1}$.

Although nothing precise is known about absolute lifetimes something can be adduced in a relative sense from the competition characteristics of related systems. In the series $\left[\left(\mathrm{NH}_{3}\right)_{5} \mathrm{CoCl}\right]^{2+}:\left[\left(\mathrm{NH}_{2} \mathrm{CH}_{3}\right)_{5} \mathrm{CoCl}\right]^{2+}$ : $\alpha \beta$-[tetraen $\mathrm{CoCl}]^{2+}$ the competition ratio for azide ion varies in the approximate order $0.1: 1: 10$. This is interpreted in the form that the intermediate's lifetime is lengthened by steric factors which stabilize the fivecoordinate species. It shows this stability by selecting the better nucleophile $\left(\mathrm{N}_{3}^{-}>\mathrm{H}_{2} \mathrm{O}\right.$ molecule for molecule). The 'trenen' ligand is of a general type 
shown to stabilize five-coordinate $\mathrm{Co}^{\mathrm{II}}$ complexes $^{70}$ and strain energy calculations and structural studies ${ }^{71}$ support the existence of steric strain in the six-coordinate reactants $\left[\left(\mathrm{NH}_{2} \mathrm{CH}_{3}\right)_{5} \mathrm{CoCl}\right]^{2+}$ and $[(\text { trenen }) \mathrm{CoCl}]^{2+}$. Usually for cobalt(III) complexes the intermediate or intermediates lead to substantial rearrangement. However, little can be said with certainty about their structure and it is likely that this is dictated substantially by the demands of the ligand geometry, at least in the multidentate systems. For the simpler systems such as $\left[\mathrm{Co}\left(\mathrm{NH}_{3}\right)_{4}{ }^{15} \mathrm{NH}_{2}\right]^{2+}$ or $\left[\mathrm{Co}\left(\mathrm{NH}_{3}\right)_{3}\left({ }^{15} \mathrm{NH}_{3}\right) \mathrm{NH}_{2}\right]^{2+}$ or $\left[\mathrm{Co}(\mathrm{en})_{2} \mathrm{NH}_{2}\right]^{2+}$ or $\left[\mathrm{Co}(\mathrm{en})_{2}(\mathrm{en}-\mathrm{H}) \mathrm{NH}_{3}\right]^{2+}$ whether one or two intermediates yield the observed stereochemistry is not yet clear. We can say however that if two or more intermediates are present then rearrangement between them is not competitive with the addition of the nucleophile ${ }^{61}$. Rearrangement if it occurs must be at least a factor of thirty faster on this time scale. However, if reprotonation of the intermediate is slow relative to its reactivity then one intermediate will accommodate all the data at the moment, provided attack by the entering group can occur in several places. Under these circumstances an intermediate such as

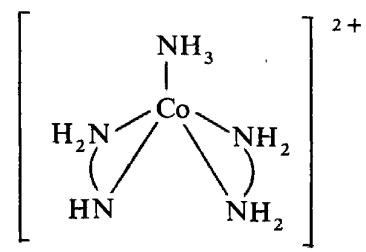

is asymmetric and could yield feasibly the required amounts of retention, inversion and trans configuration obtained from a cis substrate.

The evidence for lack of proton exchange in the intermediate is not substantial but there are some reasonable arguments for a guide ${ }^{63}$. For molecules like $\left[\mathrm{Co}\left(\mathrm{NH}_{3}\right)_{5} \mathrm{Cl}\right]^{2+}$ and cis- and trans- $\left[\mathrm{Co}(\mathrm{en})_{2} \mathrm{NH}_{3} \mathrm{Cl}\right]^{2+}$ the fastest
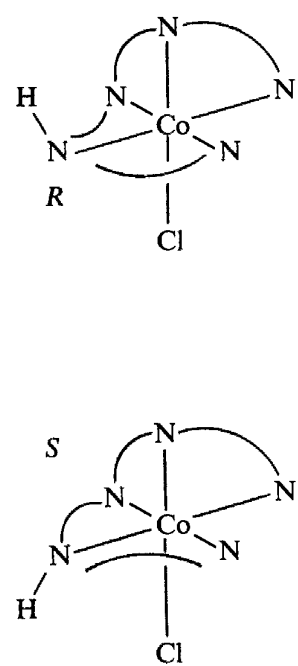

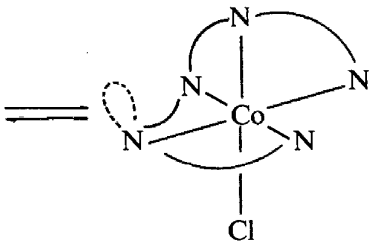

$\mathrm{OH}^{-}$

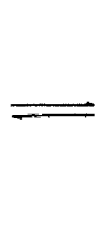

azido product
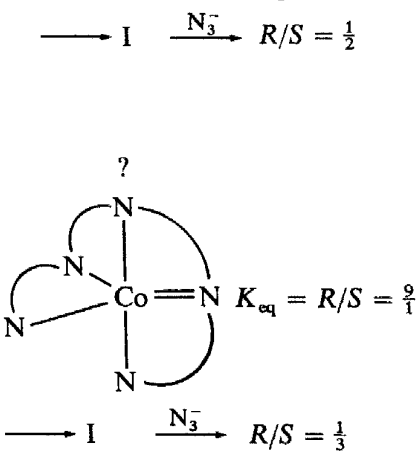

Figure 1. $\left[\mathrm{Co}(\text { tetraen) } \mathrm{Cl}]^{2+}\right.$ base hydrolysis to non-equilibrium products 
proton exchange is $\approx 10^{6} \mathrm{M}^{-1} \mathrm{~s}^{-1}$ at $25^{\circ} \mathrm{C}$ and if we assume that $\mathrm{p} K_{\mathrm{a}} \approx 16$ then the rate constant for reprotonation is $\approx 10^{8} \mathrm{~s}^{-1}$. This might also be construed as a reasonable estimate for reprotonation of the intermediate. The stereochemistry of the products is also independent of $\mathrm{pH}$ in the range 9-14 and it seems reasonable from these estimates and properties that reprotonation at least competes with capture of the nucleophile.

A recent set of experiments ${ }^{72}$ has something more to offer in terms of the structure and properties of the intermediate(s) (Figure 1). Base hydrolysis of the diastereoisomeric forms $R$ and $S$ of $\alpha, \beta$-[Co(tetraen)Cl] ${ }^{2+}$ shows that there is no mutarotation in the starting material even though $\mathrm{H}$-exchange is at least one hundred times faster than base hydrolysis. Also the products from both substrates, largely $R$ and $S \alpha, \beta$-[Co(tetraen)OH] ${ }^{2+}(\approx 30$ per cent $R$, $\approx 65$ per cent $S$ ) were quenched with acid before mutarotation ensued. The equilibrium ratio for these ions is $S / R=1 / 9$. Clearly the sec-N rearrangement occurs after the $\mathrm{Cl}^{-}$ion is lost and before $\mathrm{H}_{2} \mathrm{O}$ adds, to give the hydroxo products, i.e. in the five-coordinate intermediate stage.

These results show that deprotonation is required for the process and that the $R$ and $S$ centres joining the chelates in the same plane are those involved. Independent n.m.r. studies of proton exchange and an analysis of chemical shifts in these and related complexes lead to the evaluation that these protons are also the most acidic.

The diastereoisomers were ideal to test the question of whether a common intermediate was involved or not. If $d_{\pi}-p_{\pi}$ overlap between the filled orbital on the $\mathrm{N}$-atom and the vacated orbital on cobalt dominated the stabilization of the intermediate ${ }^{58}$, then a common intermediate and products would be expected in the form

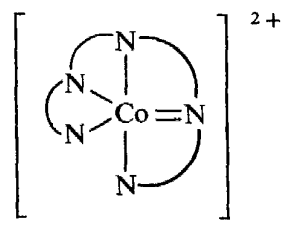

Common results did not arise from the substrates. The hydroxo products were very similar but when the reactions were carried out in $\mathrm{N}_{3}^{-}(1 \mathrm{M})$ the ratio of $S / R$ azido complex ( $\approx 90$ per cent) from $S$ chloro was substantially more (3/1) than from the $R$ chloro isomer $(2 / 1)$. We can assert therefore that $d_{\pi}-p_{\pi}$ stabilization as it was originally formulated ${ }^{58}$ does not occur, but a partial overlap of the filled p-orbital with the empty d-orbital cannot be excluded. Another isomer was detected in the products, $<5$ per cent, (reconverted to the chloro complex with retention) with vastly different rotatory dispersion characteristics from either $R$ or $S$ reactant. Presumably it has the general topology of either

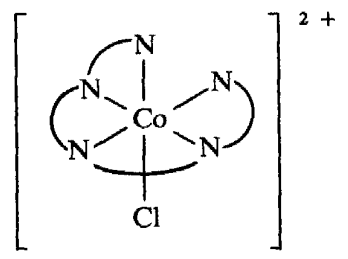

or

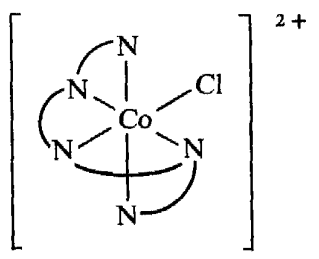


Overall the results require a subtle difference between the intermediates generated from the two sources. It is also difficult to accommodate the appearance of both $R$ and $S$ products without using two intermediates. The $\mathrm{N}_{3}^{-}$competition experiments showed that the intermediate did not rearrange competitively with $\mathrm{N}_{3}^{-}$entry and the estimates for inversion at the $\mathrm{N}$-centre are in the vicinity of $10^{3}-10^{4} \mathrm{~s}^{-1}$. It seems therefore that the two sec- $\mathrm{N}$ asymmetric environments are generated in the formation of the intermediates and that the competitors capture these two environments before rearrangement ensues. Rapid equilibration at the asymmetric centre of interest does not seem to be likely. Finally an interesting feature is that $\approx 70$ per cent of the least stable hydroxo isomer is generated from the most stable chloro isomer. This is a property which is common for high-energy intermediates in organic chemistry (although it is not a requirement) and is especially valuable for synthetic purposes.

The same phenomenon has been observed for the base hydrolysis of $\Delta \beta_{2}(R)$ [Co(trien) $\left.\left(\mathrm{NH}_{2} \mathrm{CH}_{2} \mathrm{COOC}_{2} \mathrm{H}_{5}\right) \mathrm{Cl}\right]^{2+}$ and the glycine analogue ${ }^{73}$. The products $\Delta \beta_{2}(R)-\left[\mathrm{Co}(\text { trien)gly }]^{2+} \text { and } \Delta \beta_{2}(S) \text {-[Co(trien)gly }\right]^{2+}$ were substantially enriched in $\Delta \beta_{2}(S)$ isomer (40 and 60 per cent respectively) compared with equilibrium ratio $\Delta S / \Delta R \approx 1 / 9$. Here also mutarotation was shown to occur after loss of $\mathrm{Cl}^{-}$and before $\mathrm{H}_{2} \mathrm{O}$ addition.

\section{SYNTHESIS}

One of the areas in which inorganic chemistry is destitute relative to organic chemistry is in the possibility of planned synthesis. In this respect the intermediates discussed have something to offer. They may be used for example to capture species in solution which are not thermodynamically stable and are relatively labile compared with the more stable products. A good example of this behaviour is the capture of the S- $v$. the N-end of the NCS ${ }^{-}$ ion. Both $\left[\left(\mathrm{NH}_{3}\right)_{4} \mathrm{NH}_{2} \mathrm{Co}\right]^{2+}$ and $\left[\left(\mathrm{NH}_{3}\right)_{5} \mathrm{Co}\right]^{3+}$ have been used for this purpose and in both instances the thermodynamically unstable S-bonded pentaammine was obtained in preference $(\approx 4 / 1)$. This result is also consistent with the thesis that the least solvated nucleophile atom is most likely to be captured. As far as can be judged at this time the equilibrium lies totally towards the N-bonded form $(>100 / 1)$. Following the capture of the S-bonded species a simultaneous base catalysed loss of $\mathrm{SCN}^{-}$(75 per cent) and rearrangement to the $\mathrm{N}$-bonded form ( 25 per cent) was observed. The latter was an intramolecular process and recent data indicate that an intimate ion pair may be involved which is not in equilibrium with $\mathrm{NCS}^{-}$in solution ${ }^{74}$.

A similar observation was made in the competition for $\mathrm{NO}_{2}^{-}$by [Co$\left.\left(\mathrm{NH}_{3}\right)_{4} \mathrm{NH}_{2}\right]^{2+60}$. Here the $\mathrm{N}$ atom was captured in preference to $\mathrm{O}$, whereas in the customary synthesis of nitro complexes $\mathrm{NO}^{+}$or $\mathrm{N}_{2} \mathrm{O}_{3}$ adds to coordinated $\mathrm{OH}^{-}$and a slow rearrangement to the $\mathrm{N}$-bonded form follows. Again this fits the pattern that the least solvated atom is captured but in this instance of course it coincides with the thermodynamically stable species.

The reactions in principle are applicable to any coordinating agent with one or more sites for coordination. The conditions are mild and fairly versatile both with respect to solvent and substrates so that numerous 
relatively labile species can be made, e.g. $\left[\left(\mathrm{NH}_{3}\right)_{5} \mathrm{CoOP}\left(\mathrm{OCH}_{3}\right)_{3}\right]\left(\mathrm{ClO}_{4}\right)_{3}$, $\left[\left(\mathrm{NH}_{3}\right)_{5} \mathrm{CoO}=\mathrm{C}\left(\mathrm{CH}_{3}\right)_{2}\right]\left(\mathrm{ClO}_{4}\right)_{3}$.

One of the more interesting properties of the intermediates is their ability to capture intramolecular nucleophiles. For example cis-[Co(en $)_{2}$ (glyOR)$\mathrm{Br}]^{2+}$ treated with $\mathrm{Hg}^{2+}$ leads to the chelated ester complex ${ }^{75,76}$ by capture of the carbonyl oxygen atom. This species is especially reactive. It hydrolyses rapidly in water; it adds primary and secondary amines to give chelated amides and peptides and it reacts with oxygen bases to give the anhydride intermediate and finally the chelated amino acid anion. These last reactions are not especially pertinent except that they display a range of reactions of labile substrates prepared by especially mild methods compared with the rather rigorous methods usually employed in cobalt(III) chemistry. However it is pertinent that the induced substitution reactions will be even more relevant to the second and third row transition elements where spontaneous substitution processes are frequently slow.

Similar results arise from the base hydrolysis of $c i s-\left[\mathrm{Co}(\mathrm{en})_{2}(\mathrm{glyOR}) \mathrm{Br}\right]^{2+77}$. The intermediate captures both the carbonyl oxygen atom and a water molecule to give two reaction paths detected by tracer studies. These paths lead on to direct hydrolysis of the chelated ester in one instance and the attack of the coordinated $\mathrm{OH}^{-}$nucleophile at the carbonyl function and thence hydrolysis in the other instance. Similar patterns are observed for the coordinated glycinamide ${ }^{78}$. This facility is also observed for other coordinated ligands. For example cis- $\left[\mathrm{Co}(\mathrm{en})_{2}\left(\mathrm{NH}_{2} \mathrm{CH}_{2} \mathrm{CH}_{2} \mathrm{OH}\right) \mathrm{Br}\right]^{2+}$ will react with $\mathrm{Hg}^{2+}$ or $\mathrm{OH}^{-}$to give substantially chelated ethanolamine ${ }^{79}$. In these reactions anions like $\mathrm{N}_{3}^{-}$also compete for the intermediate and the entire system is therefore rather well suited to monitor the properties of intermediates by looking at competition between internal and external nucleophiles and solvent, as well as the stereochemistry. At the moment a detailed study of such a system has not yet been carried out. In this context the reaction carried out with $\left[\mathrm{Co}(\mathrm{en})_{2}\left(\mathrm{NH}_{2} \mathrm{CH}_{2} \mathrm{CH}_{2} \mathrm{NH}_{2}\right) \mathrm{Cl}\right]^{2+}$ in aqueous base ${ }^{80}$ which failed to give appreciable amounts of $\left[\mathrm{Co}(\mathrm{en})_{3}\right]^{3+}$ is not surprising. We have seen that $\mathrm{NH}_{3}$ is a poor competitor under these circumstances and it follows that monodentate ethylenediamine should be poor also. For $-\mathrm{NH}_{2}$ to be efficient in such circumstances $\mathrm{H}$-bonding to the solvent should be reduced. Dimethyl sulphoxide for example may allow substantial chelation to be realized.

Finally the base hydrolysis of $\Delta \alpha \beta(R)-\left[\mathrm{Co}\right.$ (tetraen) $\mathrm{Cl}^{2+}, \Delta \beta_{2}(R)-[\mathrm{Co}-$ (trien) $\left(\mathrm{NH}_{2} \mathrm{CH}_{2} \mathrm{COOC}_{2} \mathrm{H}_{5}\right) \mathrm{Cl}^{2+}$ and $\Delta \beta_{2}(R)-\left[\mathrm{Co}(\right.$ trien $)\left(\mathrm{NH}_{2} \mathrm{CH}_{2} \mathrm{COO}^{-}\right)-$ $\mathrm{Cl}^{+}{ }^{+}$to give substantial amounts of the thermodynamically unstable $\Delta \beta_{2}(S)$ $[\mathrm{Co}(\text { trien }) \mathrm{gly}]^{2+}$ isomer $^{73}$ suggests that this may be a common method for generating such species. Another example of this phenomenon probably exists in the $\mathrm{Hg}^{2+}$ catalysed removal of $\mathrm{Cl}^{-}$from trans-(SS)-[Co(trien) $\left.\mathrm{Cl}_{2}\right]^{+81}$ to give largely trans $(S S)-\left[\mathrm{Co}(\operatorname{trien})\left(\mathrm{H}_{2} \mathrm{O}\right)_{2}\right]^{3+}$ which then rearranges by a path inverse in $\left[\mathrm{H}^{+}\right]$concentration to a high concentration of the unstable cis isomer, $\Lambda \beta S R$. The subsequent mutarotation of $\Lambda \beta S R$ to the equilibrium mixtures of $\Lambda \beta S R$ plus $\Lambda \beta S S$ was also observed. The path inverse in $\left[\mathrm{H}^{+}\right]$is attributed to the removal of $\mathrm{H}^{+}$at either sec- $\mathrm{N}$ centre to allow mutarotation in an intermediate on the way to the cis isomer. Also optically pure final product was obtained. Therefore little mutarotation is possible in the trans isomer since this must lead to meso and then to racemic cis complexes. 
The foregoing is not a comprehensive list of prospects and possibilities and many fruitful experiments should be possible. For example changes in solvent may drastically alter the various types of processes. Massive changes in activity coefficients occur with solvent changes and these properties have not been exploited extensively in inorganic chemistry ${ }^{82}$. Intermediates of the type described should be useful in the formation of dimers ${ }^{83}$ and even polymers. The prospect of group migration also exists when triggered by 'cobaltium' ions.

In general the preceding chemistry appears to be dissociative or largely dissociative and the reason for this might be rationalized from a crude electronic picture of these species in the following way. If a potential nucleophile aims for an antibonding orbital it is confronted with the non-bonding interactions from the six existing ligand atoms. If it approaches the face of the octahedron where the former effect is usually minimized then it encounters essentially the non-bonding electrons. At the same time seven-coordinate complexes exist even in the first row transition $\operatorname{series}^{84}$ so that expansion of the coordination sphere is possible. The previous arguments merely indicate that the process is not especially favoured.

\section{NUCLEOPHILIC REACTIONS}

It is more difficult to characterize the associative process, especially solvolysis, unless an observable intermediate is formed. In octahedral chemistry we do not generally have the special facility of inversion for each act of nucleophilic substitution that occurs in carbon chemistry. In fact stereospecific rearrangements appear to be rare. One such case is the stereospecific solvolysis $^{81,85}$ of trans $(S S)-\left[\mathrm{Co}(\operatorname{trien}) \mathrm{Cl}_{2}\right]^{+}$to $\beta(S S)-\left[\mathrm{Co}(\operatorname{trien}) \mathrm{ClH}_{2} \mathrm{O}\right]^{2+}$.
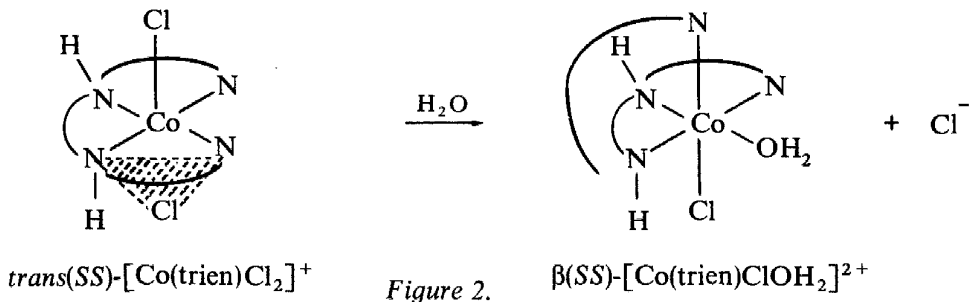

Figure 2.

$\beta(S S)-\left[\mathrm{Co}(\text { trien }) \mathrm{ClOH}_{2}\right]^{2+}$

This aquation takes place with full retention of configuration to give the optically pure $\beta$-chloro aquo isomer whose structure is depicted in Figure 2. In this reaction no competition by other anions occurs and the induced aquation with $\mathrm{Hg}^{2+}$ leads substantially to the trans chloro aquo species which then rearranges more slowly than the aquation step to the $\beta$-chloro aquo species depicted. It follows that the trans chloro aquo ion cannot be an intermediate in the spontaneous aquation and when an intermediate is generated it follows a different stereochemical path. We infer therefore that a water molecule plays a special role at the octahedral face hatched in Figure 2 and its equivalent about the $C_{2}$ axis. The properties of the reaction are consistent with $\mathrm{Co}-\mathrm{Cl}$ bond stretching as the leading process, with synchronous addition of water as $\mathrm{Cl}^{-}$leaves in a minor role. 


\section{A. M. SARGESON}

The implication in the earlier arguments is that a strong dependence on bond making will only be observed if at all for the most potent nucleophiles. It is almost axiomatic that these species will also be good reducing agents and reduction may be a preferred process over ligand entry. In fact a distinction between the two processes may be difficult in some instances.

Complexes like $\left[\left(\mathrm{NH}_{3}\right)_{5} \mathrm{CoNCS}\right]^{2+}$ and $\left[\left(\mathrm{NH}_{3}\right)_{5} \mathrm{CoF}\right]^{2+}$ react rapidly with mercaptide ions (e.g. $\mathrm{HOCH}_{2} \mathrm{CH}_{2} \mathrm{~S}^{-}$), in fact much faster than base hydrolysis of $\mathrm{NCS}^{-}$or $\mathrm{F}^{-}$at $\mathrm{pH} 11$. When the reaction is quenched after a few seconds (10-20 per cent reaction) an intensely coloured product and unreacted material may be recovered. The highly coloured product has a charge in excess of $3+$ and is presumably a polymer of $\mathrm{Co}^{\mathrm{n}}$. At this time it is not clear if substitution has occurred, followed by a rapid redox process, or if the $\mathrm{Co}^{\mathrm{III}}$ species is reduced initially by the mercaptide ion. The analogous $\mathrm{Cr}^{\mathrm{III}}$ species however does not undergo an analogous reaction. Here the $\mathrm{Cr}^{\mathrm{II}}$ state is much less accessible and $\mathrm{Cr}^{\mathrm{II}}$ should be more susceptible to nucleophilic attack. The inference is therefore that the $\mathrm{Co}^{\mathrm{II}}$ reaction is reduction and not substitution.

\section{ELECTROPHILIC SUBSTITUTION}

If nucleophilic attack is aborted by these electronically rich systems then the prospect for electrophilic reactions should be substantial. Superficially they do not seem to be common but one of the problems perhaps is that we have not learned to recognize them readily. However several octahedral electrophilic reactions are well characterized and one of the best of these is the rapid attack of NO on $\left[\left(\mathrm{NH}_{3}\right)_{6} \mathrm{Ru}\right]^{3+86}$. The rate law for this $\left[\left(\mathrm{NH}_{3}\right)_{6} \mathrm{Ru}\right]^{3+}$ $+\mathrm{NO}+\mathrm{H}^{+} \rightarrow\left[\left(\mathrm{NH}_{3}\right)_{5} \mathrm{RuNO}\right]^{3+}+\mathrm{NH}_{4}^{+}$process is first order in the radical NO and first order in the $\mathrm{d}^{5}$-system. Also the rate of entry of NO $\left(k=0.2 \mathrm{M}^{-1} \mathrm{~s}^{-1}, 25^{\circ} \mathrm{C}\right)$ is much faster than $\mathrm{H}$-exchange on the coordinated ammonia molecules $\left(\approx 10^{-6} \mathrm{M}^{-1} \mathrm{~s}^{-1}\right)^{87}$. The same process applied to $\left[\left(\mathrm{NH}_{3}\right)_{5} \mathrm{RuBr}\right]^{2+}$ gives approximately equal amounts of $\left[\left(\mathrm{NH}_{3}\right)_{5} \mathrm{RuNO}\right]^{3+}$ and $\left[\left(\mathrm{NH}_{3}\right)_{4} \mathrm{RuNOBr}\right]^{2+}$. Presumably $\mathrm{NO}$ directly attacks the partially filled $t_{2 g}$ orbital and there is evidence that there is an equivalent intermediate generated by the attack of $\mathrm{NO}^{+}$on $\left[\left(\mathrm{NH}_{3}\right)_{6} \mathrm{Ru}\right]^{2+88}$. A similar situation arises with osmium complexes; $\left[\left(\mathrm{NH}_{3}\right)_{6} \mathrm{Os}\right]^{2+}$ and $\mathrm{NO}^{+}$yield $\left[\left(\mathrm{NH}_{3}\right)_{5} \mathrm{Os}_{-}\right.$ $\left.\mathrm{N}_{2}\right]^{2+89}$. Here also proton exchange on the ammonia groups is too slow to allow nitrosation of the $\mathrm{Os}-\mathrm{NH}_{2}^{-}$ion ${ }^{87}$. Presumably $\mathrm{NO}^{+}$adds first to the metal orbital and then competes with the metal for $\mathrm{NH}_{3}$. In addition protonactivated substitution accounts for the lability of ammonia molecules in $\left[\mathrm{Ru}\left(\mathrm{NH}_{3}\right)_{6}\right]^{2+}$ in acidic solution ${ }^{90}$.

Evidence for electrophilic processes in the first row transition elements is more scanty and this may reflect the contracted d-orbitals for these ions, relative to the second and third row elements. However $\left[\mathrm{Fe}(\mathrm{CN})_{6}\right]^{3-}$ and NO appear to give $\left[\mathrm{Fe}(\mathrm{CN})_{5} \mathrm{NO}\right]^{3-91}$. Also the acid-catalysed racemization and aquation of complexes like $\left[\mathrm{Fe}(\text { bipy })_{3}\right]^{2+}$ and $\left[\mathrm{Ni}(\text { bipy })_{3}\right]^{2+}$ might be rationalized as electrophilic attack of $\mathrm{H}^{+}$at the metal rather than at the ligand. The reactions between $\left[\left(\mathrm{NH}_{3}\right)_{5} \mathrm{CoBr}\right]^{2+}$ and $\mathrm{ClOH}$, and $\left[\left(\mathrm{NH}_{3}\right)_{5} \mathrm{CrBr}\right]^{2+}$ and $\mathrm{ClOH}$, to give the aquo complexes are interpreted as addition of $\mathrm{HO}^{+92}$. In 
addition the $\mathrm{Cr}$ moiety is much more reactive than $\mathrm{Co}$ and this implies some participation by the d-orbitals ${ }^{94}$.

Even from this limited and rather superficial survey it should be clear that little advance has been made in characterization of nucleophilic and electrophilic processes and that there is largely an unexploited potential for the use of intermediates of reduced coordination number in the synthesis of complexes.

\section{ACKNOWLEDGMENT}

Dr D. A. Buckingham and I wish to record our appreciation to many colleagues, past and present, whose contributions are documented widely in this article.

\section{REFERENCES}

1 J. E. Byrd and W. K. Wilmarth, Inorg. Chim. Acta Rev., 7 (1971).

2 J. Halpern, R. A. Palmer and L, M. Blakely, J. Am. Chem. Soc., 88, 2877 (1966).

3 D. R. Stranks and J. Yandell, Inorg. Chem., 9, 751 (1970).

4 D. Thusius, J. Am. Chem. Soc., 93, 2629 (1971).

5 L. M. Dudwick and T. L. Brown, J. Am. Chem. Soc., 91, 5188 (1969).

6 E. B. Fleischer, S. Jacobs and L. Mestichelli, J. Am. Chem. Soc., 90, 2527 (1968).

7 G. Costa, G. Mestroni, G. Tauzher, D. Goodall, M. Green and H. A. O. Hill, Chem. Commun., 34 (1970).

8 D. Robb, M. M. Steyn and H. Kruger, Inorg. Chim. Acta, 3, 383 (1969).

9 T. J. Swift and R. E. Connick, J. Chem. Phys., 37, 307 (1962); 41, 2553 (1964).

10 J. P. Hunt, Coord. Chem. Rev., 7, 1 (1971).

11 H. Diebler, M. Eigen, G. Iegenfritz, G. Maass and R. Winkler, Pure and Appl. Chem., 20, 93 (1969).

12 H. R. Hunt and H. Taube, J. Am. Chem. Soc., 80, 2642 (1958).

13 N. V. Duffy and J. E. Earley, J. Am. Chem. Soc., 89, 272 (1967).

14 F. Monacelli, Inorg. Chim. Acta, 2, 263 (1968).

15 F. Monacelli and E. Viel, Inorg. Chim. Acta, 1, 467 (1967).

16 E. Borghi and F. Monacelli, Inorg. Chim. Acta, 5, 211 (1971).

17 C. H. Langford and W. R. Muir, J. Am. Chem. Soc., 89, 3141 (1967).

18 H. L. Bott, A. J. Poe and K. Shaw, Chem. Commun., 793 (1968).

19 J. W. Moore and R. G. Pearson, Inorg. Chem., 3, 1334 (1964).

20 F. Basolo and R. G. Pearson. Mechanisms of Inorganic Reactions, p. 159, 2nd ed., John Wiley and Sons, Inc., New York (1967).

21 C. H. Langford, Inorg. Chem., 4, 265 (1965).

22 A. Haim, Inorg. Chem., 9, 426 (1970).

23 W. E. Jones, L. R. Carey and T. W. Swaddle, in the press.

${ }^{24}$ F. A. Posey and H. Taube, J. Am. Chem. Soc., 79, 255 (1957).

25 A. Haim and H. Taube, Inorg. Chem., 2, 1199 (1963).

26 D. A. Buckingham, I. I. Olsen, A. M. Sargeson and H. Satrapa, Inorg. Chem., 6, 1027 (1967).

27 J. Sullivan, private communication.

${ }^{28}$ R. J. Balahura and R. B. Jordan, Inorg. Chem., 9, 1567 (1970).

29 D. J. Francis, unpublished work.

30 P. C. Ford, Inorg. Chem., 10, 2153 (1971).

${ }^{31}$ H. Siebert and H. Feuerhake, Chem. Ber., 102, 2951 (1969).

32 W. Marty, unpublished work.

${ }_{33}$ D. A. Loeliger and H. Taube, Inorg. Chem., 5, 1376 (1966).

${ }^{34}$ D. A. Buckingham, I. I. Olsen and A. M. Sargeson, Inorg. Chem., 6, 1807 (1967).

${ }^{35}$ C. K. Ingold, R. S. Nyholm and M. L. Tobe, Nature, 187, 477 (1960).

36 C. G. Barraclough, R. W. Boschen, W. W. Fee, W. G. Jackson and P. T. McTigue, Inorg. Chem., 10, 1991 (1971).

37 D. A. Buckingham, I. I. Creaser and A. M. Sargeson, Inorg. Chem., 9, 655 (1970). 

and references therein.

${ }^{55}$ F. R. Nordmeyer, Inorg. Chem., 8, 2780 (1969).

56 P. J. Cresswell, unpublished work.

57 Reference 20, p. 187.

58 R. G. Pearson and F. Basolo, J. Am. Chem. Soc., 78, 4878 (1956).

59 H. Taube and M. Green, Inorg. Chem., 2, 948 (1963).

60 D. A. Buckingham, I. I. Olsen and A. M. Sargeson, J. Am. Chem. Soc., 88, 5443 (1966).

61 D. A. Buckingham, I. I. Olsen and A. M. Sargeson, J. Am. Chem. Soc., 90, 6654 (1968).

62 A. Panunzi and F. Basolo, Inorg. Chim. Acta, 1, 223 (1967).

${ }^{63}$ D. A. Buckingham, I. I. Olsen and A. M. Sargeson, J. Am. Chem. Soc., 90, 6539 (1968).

${ }^{64}$ R. B. Jordan and A. M. Sargeson, Inorg. Chem., 4, 433 (1965).

65 D. A. Buckingham, B. M. Foxman and A, M. Sargeson, Inorg. Chem., 9, 1790 (1970).

66 B. M. Foxman, Chem. Commun., 515 (1972).

67 D. A. Buckingham, B. M. Foxman and A. M. Sargeson, to be published.

68 W. Marty, unpublished work.

69 Reference 60 and unpublished work.

${ }^{70}$ L. Sacconi, Pure and Appl. Chem., 17, 95 (1968).

71 M. Dwyer, P. J. Cresswell and B. M. Foxman, unpublished work.

72 D. A. Buckingham, B. M. Foxman, P. A. Marzilli, A. J. Herlt and A. M. Sargeson, unpublished work.

${ }^{73}$ L. G. Marzilli, W. Marty and K. R. Turnbull, unpublished work.

74 D. A. Buckingham, I. I. Creaser, W. Marty and A. M. Sargeson, Inorg. Chem., in the press.

${ }^{75}$ M. D. Alexander and D. H. Busch, J. Am. Chem. Soc., 88, 1130 (1966).

${ }^{76}$ D. A. Buckingham, D. M. Foster and A. M. Sargeson, J. Am. Chem. Soc., 90, 6032 (1968).

77 D. A. Buckingham, D. M. Foster and A. M. Sargeson, J. Am. Chem. Soc., 91, 4102 (1969).

${ }^{78}$ D. A. Buckingham, D. M. Foster and A. M. Sargeson, J. Am. Chem. Soc., 92, 6151 (1970).

79 D. A. Buckingham, C. E. Davis and A. M. Sargeson, J. Am. Chem. Soc., 92, 6159 (1970).

${ }^{80}$ M. D. Alexander and C. A. Spillert, Inorg. Chem., 9, 2344 (1970).

81 D. A. Buckingham, P. A. Marzilli and A. M. Sargeson, Inorg. Chem., 6, 1032 (1967).

82 A. J. Parker, Chem. Rev., 69, 1 (1969).

83 G. Schwarzenbach, J. Boesch and H. Egli, J. Inorg. Nucl. Chem., 35, 2141 (1971).

84 M. D. Lind, M. J. Hamor, T. A. Hamor and J. L. Hoard, Inorg. Chem., 3, 34 (1964).

85 A. M. Sargeson and G. H. Searle, Inorg. Chem., 6, 2172 (1967).

86 J. N. Amor, H. Scheidegger and H. Taube, J. Am. Chem. Soc., 90, 5928 (1968).

87 J. W. Palmer and F. Basolo, J. Inorg. Nucl. Chem., 15, 279 (1960).

88 F. M. Lever and A. R. Powell, Chem. Soc. Special Publication, 13, 135 (1959).

89 H. Scheidegger, J. N. Amor and H. Taube, J. Am. Chem. Soc., 90, 3263 (1968).

90 P. C. Ford, J. R. Kuempel and H. Taube, Inorg. Chem., 7, 197 (1968).

91 P. Schwarzkopf, Chem. Abstr., 8, 1106 (1914).

92 A. Haim and H. Taube, J. Am. Chem. Soc, 85, 3108 (1963). 